\title{
Values Education Research Trends in Turkey: A Content Analysis ${ }^{1}$
}

\author{
Adem Belda \\ Correspondence: Adem Beldağ, Department of Elementary Education, Recep Tayyip Erdoğan University, 53200, Çayeli, \\ Rize, Turkey
}

Received: January 22, 2016

Accepted: February 22, 2016

Online Published: March 3, 2016

doi:10.11114/jets.v4i5.1325

URL: http://dx.doi.org/10.11114/jets.v4i5.1325

\begin{abstract}
The present study makes a situation analysis of graduate theses on values education published between 1999 and 2015 in Turkey. It has a qualitative research design, wherein data is collected through document analysis. The form developed for this purpose is comprised of nine sections, each of which focuses on a different aspect: universities, education levels, departments/programs, topics, research models, methodologies, sampling strategies, data collection instruments, and data analysis techniques. A total of 126 graduate theses were analyzed. The data was analyzed by means of content analysis. The study revealed that, of 126 theses, 106 were master's theses, and 20 were doctoral theses; the highest number of theses on values education were submitted in 2013, and the most frequently studied topic was students' values. It was also found that qualitative methods were the most common research methods, and survey was the most common research model. Finally, random sampling was found to be the most common sampling technique.
\end{abstract}

Keywords: Values education, values, research trends, trends in values education, content analysis

\section{Introduction}

Value is a concept that has been much debated throughout the history of mankind, and it has maintained its importance since the beginning of philosophy (Özlem, 2010). As a field of philosophy, it has emerged as the source and existence cause of the discipline dealing with values such as good-bad, and beautiful-ugly (Arslan, 2005). The related literature defines the concept of value as the set of believes influencing the human conduct (Ulusoy and Dilmaç, 2012), or the belief pertaining to whether or not something is worth desiring (Güngör, 1998). It can also be defined as the elements influencing the behaviors of human beings throughout their lives and shaping their lifestyles (Yel and Aladağ, 2009), or the thoughts that we give importance to and that affect our lives (Doğanay, 2006). Cevizci (2006) defines it as a base of belief resorted to, which affects and gives meaning to daily life, and a value which entails both economic value and worth.

Values education helps form individuals' perception of social responsibility influencing their decisions and acts (Stephenson et.al, 1998) and is provided at schools through both instructional programs and hidden curricula (Tarman and Kuran, 2014; Akbaş, 2004). Thus, it is considered to be fundamental to the welfare of a democratic society (Akbaş, 2004). Elkatmış (2009), on the other hand, defines values education in general terms as the teaching of values explicitly and deliberately. Values education can also be defined as a value gaining activity; this has been a central element in the Turkish education programs since the radical changes introduced in 2005-2006 academic year. This is why schools have a vital role in the implementation of values education. They not only shape but also reflect societal values (Halstead, 1996). Children are sent to school so that they can gain ideal behaviors, become productive citizens, and learn their own history and traditions, as well as the values of a democratic society (DeRoche and Williams, 1998). The goals of values education and those of school agree with each other.

Values education had not had a systematic and organized place with an official title such as "values education" within the curricula before 2005, yet, starting from 1924, several traces of values have prevailed in all official curricula of the Turkish Republic. Values can be seen, though in varied forms, in courses in the curricula and content of courses, as well as in the fundamental principles of the education system of the Turkish Republic (Akyüz, 2013). Indeed, the statement in MEB (1973) which reads “... adopting, preserving, and enhancing Turkish nation's national, moral, human, spiritual,

\footnotetext{
1 Early findings from this study were presented by Dr. Adem Beldağ, on 6 November 2014, at the IInd National Congress on Values Education, University of Kirıkkale, Turkey
} 
and cultural values" highlights the importance of culture transference through the education system.

The number of theses and academic research focusing on values education has increased dramatically since 2005 . To shed light on the quality of the increase in quantitative studies, different variables should be analyzed (Karadağ, 2010). Thus, the researchers can be oriented towards new perspectives and fields of study. Turan, Karadağ, Bektaş and Yalçın (2014) assert that scientific studies aiming to investigate a certain field will shed light onto the depth and breadth of that field, as well as depicting its overall status. In fact, there are studies in the literature which aimed to depict overall the studies on values education regarding different periods and perspectives (Baş and Beyhan, 2012; Adıgüzel and Ergünay, 2012; Elbir and Bağc1, 2013; Güçlü, 2015).

The fact that post graduate studies focusing on values education increased dramatically in Turkey especially after 2005 should be analyzed from the viewpoint of several variables, and the trends in these studies should be identified. Having detailed insight into various aspects of the methodologies used in these studies is of utmost importance for future research and for the establishment of Turkey's educational policies (Turan et al., 2014). By the help of the present study, it is hoped that the research orientations in values education field will be identified and gaps will be discovered. To this end, the following research questions were formulated to guide the research:

- What is the distribution of graduate theses according to the graduate level (master's-doctoral)?

- What is the distribution of graduate theses according to universities?

- What is the distribution of graduate theses according to their topics?

- What is the distribution of graduate theses according to the department/program?

- What is the distribution of graduate theses according to research design?

- What is the distribution of graduate theses according to research methodologies?

- What is the distribution of graduate theses according to data collection instruments?

- What is the distribution of graduate theses according to sampling strategies?

- What is the distribution of graduate theses according to data analysis techniques?

\section{Method}

The study has a qualitative research design, which is based on the belief that not all phenomena can be analyzed experimentally and that facts are formed on societal foundations (Denzin and Lincoln, 2005). The data was collected through document analysis. According to Merriam (2009), data obtained from documents can provide data similar to that obtained from observations and interviews, besides functioning in a myriad of ways such as revealing descriptive data, predicting hypotheses, developing new hypotheses and categories, suggesting a historical perspective, and tracing change and progress.

\subsection{Population/Sample}

The population of the study is the graduate theses on values education submitted in 1999-2015 in Turkey, which were accessed on the database of national thesis center of the Council of Higher Education. No sampling was performed because all of the 126 theses written on values education in 1999-2015 were accessed without any exception.

\subsection{Data Collection Instruments}

The data was collected by a form developed by the researcher. A tentative version of the form was developed based on an extensive analysis of the related literature. This preliminary form was evaluated by three experts, one of whom held a doctoral degree in languages, and the pilot study was carried out. As part of the pilot run, 30 theses studies in the field of values education were examined, and data was analyzed. Validity of the form was ensured after the identification and sorting of problems in practice. The text of the form is comprised of nine sections analyzing the theses from the viewpoint of universities, education levels, departments/programs, topics, research models, methodologies, sampling strategies, data collection instruments, and data analysis. To ensure reliability, the theses were double-examined. The outside examiner of the theses was a researcher who holds a doctoral degree in the field and has publications on values education. When there is a discrepancy between the codes, the examiners negotiated.

\subsection{Data Analysis}

Content analysis technique was used in data analysis, which can also be defined as the process of bringing to surface the meaning of data (Merriam, 2009). This technique refers to an endeavor towards reducing and attaching meaning to the voluminous qualitative data by identifying the basic threads in it (Patton, 2002). It was preferred in this study as it clusters related data around concepts and themes so that it can gain a form understandable to the reader (Yildirım and Şimşek, 2011). The data collected by content analysis was sorted in percentages and frequencies. The numerical data 
obtained was displayed through tables and graphs.

\section{Results}

Data was collected through a form developed by the researcher. It was analyzed based on the research questions and presented accordingly.

\subsection{Findings Related to Level of Theses (Master's/Doctoral)}

Figure 1 presents the level of graduate theses written in 1999-2015, and their distribution according to years. Of the 126 theses analyzed within the scope of the study, $106(84.1 \%)$ were master's theses, and $20(15.9 \%)$ were doctoral theses. The first graduate theses written on values education were master's theses submitted in 1999. The first doctoral thesis, however, was submitted in 2004. Only one master's thesis was submitted in 2005, after which a marked increase took place in the number of master's theses. Indeed, 8 theses (6 master's and 2 doctoral) were submitted in 2007, 9 ( 8 master's and 1 doctoral) in 2008, 13 (11 master's and 2 doctoral) in 2009, 11 (9 master's and 2 doctoral) in 2010, 14 (13 master's and 1 doctoral) in 2011, and 13 (10 master's and 3 doctoral) in 2012. The number of graduate theses on values education rocketed to 30 in 2013, with 25 master's and 5 doctoral theses. Despite a decrease in this number in 2014, 21 master's and 3 doctoral theses were submitted.

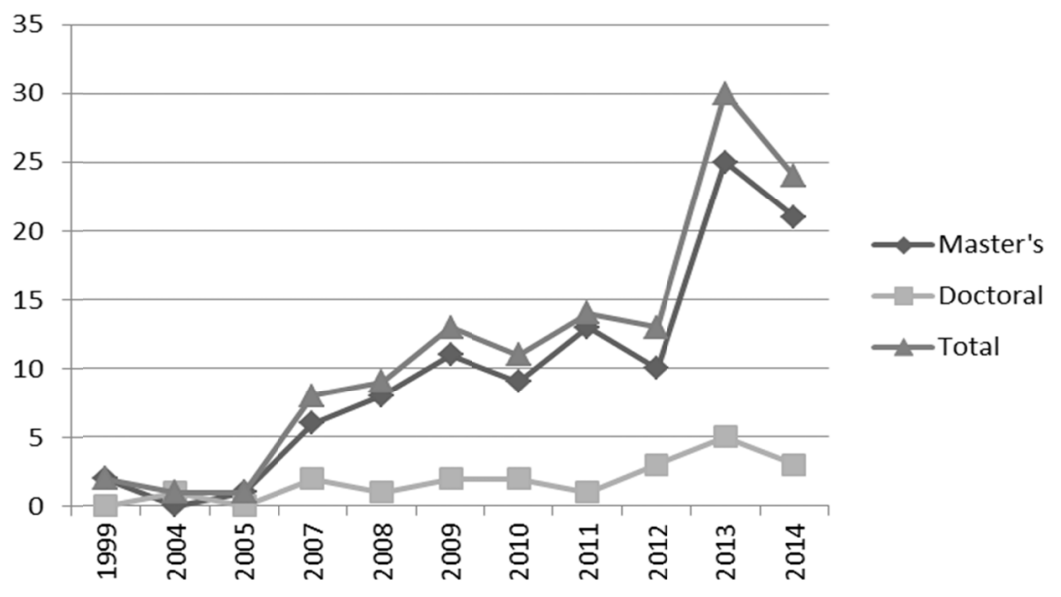

Figure 1. Levels of theses according to years

\subsection{Distribution of Theses according to Universities}

This section presents the results of the analysis of theses on values education according to universities in frequency and percentage. As can be seen in Appendix A, theses on values education have been submitted in 44 universities. Yeditepe University has made the major contribution to the field with the highest frequency (14 theses), which is followed by Marmara University (12 theses), Gazi University (9 theses), and Atatürk University (8 theses). Other universities contributed to the field with fewer theses: Hacettepe University (5), Selçuk University (4), Çanakkale on Sekiz Mart, İnönü, Karadeniz Teknik, Necmettin Erbakan, Yüzüncü Yıl, and Uşak Universities (4 each). Three graduate theses were submitted in each of the following universities: Erciyes, Firat, Mustafa Kemal, and Sakarya. The following universities contributed to the literature, each with two theses studies: Celal Bayar, Dumlupınar, İstanbul, Nigde, Uludağ, Zonguldak Karaelmas, Ondokuz Mayıs, Abant İzzet Baysal and Akdeniz. The universities which contributed to the field with one thesis only are as follows: Anadolu, Ankara, Çukurova, Dicle, Ege, Erzincan, Eskişehir Osmangazi, Gaziosmanpaşa, Hitit, Kocaeli, Mehmet Akif Ersoy, Mersin, Muğla, Orta Doğu Teknik, Pamukkale, Yıldırım Beyazıt, Adnan Menderes, Afyon Kocatepe, and Aksaray..

Distribution of thesis levels (master's/doctoral) across universities was also analyzed. The greatest number of master's thesis was submitted in Yeditepe University ( $\mathrm{f}=14,14.8 \%$ ), which is followed by Marmara University $(\mathrm{f}=11,10.3 \%$ ). Gazi Atatürk University ( $\mathrm{f}=5,4.7 \%)$ was ranked the third. Similarly, İnönü, Karadeniz Teknik, Yüzüncü Yıl, and Uşak Universities have produced a remarkable number of master's theses $(\mathrm{f}=4,3.7 \%)$. As regards the doctoral level, some observations are noteworthy. Most of the doctoral theses were written $(\mathrm{f}=4,20 \%)$ in Gazi University, as well as in Atatürk and Selçuk Universities ( $\mathrm{f}=3,15 \%)$. Hacettepe University follows these universities $(\mathrm{f}=2,10 \%)$.

\subsection{Findings Related to Topical Distribution of Theses}

Table 1 presents the results of analysis of theses on values education as regards the distribution of topics according to years. As can be seen here, the most frequently studied topic is the values of students ( $\mathrm{f}=39,30.9 \%)$, which is followed by the values in literary works ( $\mathrm{f}=38,30.1 \%)$. Also widely studied are values of teachers-administrators ( $\mathrm{f}=29,23 \%)$, 
values in the curriculum $(\mathrm{f}=17,13.4 \%)$, and values in the course books $(\mathrm{f}=3,2.3 \%)$.

Table 1 demonstrates that a graduate thesis on students' values and values in the curriculum was submitted in 1999; a thesis on students' values was submitted in 2004, and another one on the values in curriculum was submitted in 2005. The frequency of central themes according to years is as follows: 2007 ( $\mathrm{f}=3$ ) and 2008 ( $\mathrm{f}=4$ ), values of teachers-administrators; $2009(\mathrm{f}=5)$, students' values; $2010(\mathrm{f}=3)$, values of teachers-administrators; 2011 ( $\mathrm{f}=7)$, students'values; 2012 ( $\mathrm{f}=7)$, values in literary works; 2013 ( $\mathrm{f}=8$ each), students values, values in literary works, values of teachers-administrators; $2014(\mathrm{f}=10)$, values in literary works.

Table 1. Distribution of thesis topics according to years

\begin{tabular}{|c|c|c|c|c|c|c|c|c|c|c|c|c|c|}
\hline Thesis level & ळे & ষ্ণ & $\stackrel{n}{8}$ & 웡 & $\stackrel{\infty}{8}$ & \&ి & $\stackrel{0}{\circ}$ & $\overline{\vec{D}}$ & $\stackrel{\sim}{\stackrel{N}{\sim}}$ & $\stackrel{m}{\stackrel{n}{2}}$ & $\underset{⿱ 亠}{\stackrel{D}{~}}$ & 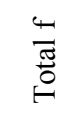 & $\frac{0^{\circ}}{\sigma_{0}^{\circ}}$ \\
\hline $\begin{array}{ll}\text { Values } & \text { of } \\
\text { students } & \end{array}$ & 1 & 1 & & 2 & 3 & 5 & 2 & 7 & 3 & 8 & 7 & 39 & 30.9 \\
\hline $\begin{array}{l}\text { Values in } \\
\text { literary works }\end{array}$ & & & & 2 & 2 & 1 & 3 & 5 & 7 & 8 & 10 & 38 & 30.1 \\
\hline $\begin{array}{l}\text { Values of } \\
\text { teachers- } \\
\text { administrators }\end{array}$ & & & & 3 & 4 & 4 & 3 & 1 & 3 & 8 & 3 & 29 & 23 \\
\hline $\begin{array}{l}\text { Values in } \\
\text { curriculum }\end{array}$ & 1 & & 1 & 1 & & 2 & 2 & 1 & & 5 & 4 & 17 & 13.4 \\
\hline $\begin{array}{l}\text { Values in } \\
\text { course books }\end{array}$ & & & & & & 1 & 1 & & & 1 & & 3 & 2.3 \\
\hline
\end{tabular}

3.4 Analysis of Theses according to Departments

Table 2 displays the frequency and percentage values pertaining to the distribution of graduate theses on values education according to the departments/programs to which they were submitted and their publication years. It demonstrates that the greatest number of theses were written in educational sciences $(\mathrm{f}=43,34.1 \%)$, which is followed by primary education $(\mathrm{f}=36,28.5 \%)$. These two departments together seem to have produced the major portion of all the theses written related to this subject $(\mathrm{f}=79,62.6 \%)$. The number of theses written in other departments is also noteworthy: Turkish language education ( $\mathrm{f}=19,15 \%)$, Religious Education $(\mathrm{f}=17,13.4 \%)$, social fields $(\mathrm{f}=4,3.1 \%)$, and child development $(\mathrm{f}=3,2.3 \%)$. It was also seen that post graduate theses were written in the departments of Turkish Language and Literature $(\mathrm{f}=2,1.5 \%)$, as well as Music, and Business administration $(\mathrm{f}=1,0.7 \%)$. The relation between the departments/programs to which the theses were submitted and their publication years was also analyzed, which revealed that, in years $2007(f=4), 2008(f=5), 2009(f=7)$, and $2010(f=5)$, most theses were submitted to the department of educational sciences, and in years $2013(\mathrm{f}=12)$ and $2014(\mathrm{f}=7)$, most theses were written in elementary childhood education program. In $2010(\mathrm{f}=4)$, however, most theses were written in Turkish language education. 
Table 2. Departments theses were submitted to according to years

\begin{tabular}{|c|c|c|c|c|c|c|c|c|c|c|c|c|c|}
\hline Thesis degree & ลे & ঠ & ஜ & હ̊요 & $\stackrel{\infty}{\bigodot}$ & ஓి & $\stackrel{\circ}{\stackrel{0}{0}}$ & $\bar{\Xi}$ & $\frac{\sim}{\grave{2}}$ & $\frac{n}{\stackrel{n}{0}}$ & $\underset{\circlearrowright}{\stackrel{\nu}{ঠ}}$ & $\frac{4}{\stackrel{\pi}{0}}$ & $\frac{\partial 0}{\stackrel{\pi}{0}}$ \\
\hline $\begin{array}{l}\text { Educational } \\
\text { Sciences }\end{array}$ & 1 & 1 & & 4 & 5 & 7 & 5 & 2 & 3 & 9 & 6 & 43 & 34.1 \\
\hline $\begin{array}{l}\text { Primary } \\
\text { education }\end{array}$ & 1 & & & 1 & 2 & 4 & 2 & 4 & 3 & 12 & 7 & 36 & 28.5 \\
\hline $\begin{array}{l}\text { Turkish language } \\
\text { education }\end{array}$ & & & & 2 & 2 & 1 & 4 & 3 & 4 & 1 & 2 & 19 & 15 \\
\hline $\begin{array}{l}\text { Religious } \\
\text { Education }\end{array}$ & & & 1 & & & & & 3 & 1 & 6 & 6 & 17 & 13.4 \\
\hline Social fields & & & & 1 & & & & & 2 & 1 & & 4 & 3.1 \\
\hline $\begin{array}{l}\text { Child } \\
\text { development }\end{array}$ & & & & & & & & 2 & & 1 & & 3 & 2.3 \\
\hline $\begin{array}{l}\text { Turkish language } \\
\text { and literature }\end{array}$ & & & & & & & & & & & 2 & 2 & 1.5 \\
\hline Music & & & & & & & & & & & 1 & 1 & 0.7 \\
\hline $\begin{array}{l}\text { Business } \\
\text { administration }\end{array}$ & & & & & & 1 & & & & & & 1 & 0.7 \\
\hline
\end{tabular}

\subsection{Findings Related to Research Models Used in Theses}

Table 3 displays the distribution of research models used in theses according to years between 1999 and 2015 in percentages. As can be seen in the table, the 126 graduate theses, which were analyzed, employed 10 different research models. Nearly half of the 126 studies (49.6) used the survey method. Other research methods are in the following frequency order: experimental (12\%), qualitative (11.2\%), mixed (8.8\%), document analysis $(8 \%)$, and correlational (5.6\%). Causal comparative method was used in two studies, so was the case study model. Action research and grounded theory models were each used in one study. A remarkable increase in the use of particularly qualitative and correlational models has taken place. Experimental and document analysis techniques were observed to be the most widely used models in 1999, while survey method was observed to be the most widely used one between 2004 and 2015.

Table 3. Distribution of research models across years

\begin{tabular}{|c|c|c|c|c|c|c|c|c|c|c|c|c|c|}
\hline Thesis Models & बे & ষ্ণ & ஜे & ఠ్ & 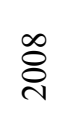 & $\stackrel{8}{8}$ & $\stackrel{\circ}{\stackrel{2}{\sim}}$ & $\overline{\bar{i}}$ & $\stackrel{\sim}{\stackrel{\sim}{*}}$ & $\stackrel{m}{\stackrel{n}{i}}$ & $\underset{\sim}{\stackrel{\Xi}{\vec{D}}}$ & $\frac{4}{\frac{\pi}{0}}$ & $\frac{\partial^{0}}{\frac{\pi}{0}}$ \\
\hline Survey & & 1 & 1 & 5 & 7 & 8 & 8 & 7 & 6 & 12 & 7 & 62 & 49.2 \\
\hline Experimental & 1 & & & 1 & 1 & 2 & 1 & 1 & & 4 & 4 & 15 & 11.9 \\
\hline Qualitative & & & & 1 & & 1 & & & 1 & 7 & 4 & 14 & 11.1 \\
\hline Mixed & & & & 1 & & 1 & 1 & 1 & 2 & 3 & 2 & 11 & 8.7 \\
\hline Document analysis & 1 & & & & & & & 2 & 3 & 2 & 3 & 11 & 8.7 \\
\hline Correlational & & & & & & 1 & & & 1 & 2 & 3 & 7 & 5.5 \\
\hline $\begin{array}{l}\text { Causal } \\
\text { comparative }\end{array}$ & & & & & & & & 1 & & & 1 & 2 & 1.5 \\
\hline Case study & & & & & & & 1 & 1 & & & & 2 & 1.5 \\
\hline Action research & & & & & 1 & & & & & & & 1 & 0.7 \\
\hline Grounded theory & & & & & & & & 1 & & & & 1 & 0.7 \\
\hline
\end{tabular}




\subsection{Findings Related to Research Methods Used in Theses}

Figure 2 displays the research methods used in graduate theses on values education in Turkey and their distribution across years. According to this, the research models used in the 126 theses analyzed in this study fall into three categories. Approximately half of these studies $(\mathrm{f}=61,48.4 \%)$ used qualitative methods. The second most frequently used research model is the quantitative model ( $\mathrm{f}=44,34.9 \%$ ), which is followed by mixed methods $(\mathrm{f}=21,16.6 \%)$. An analysis of research methodology orientations across years revealed that, between 1999 and 2011, the most common methodologies were quantitative methods, which were replaced by qualitative methods after 2011.

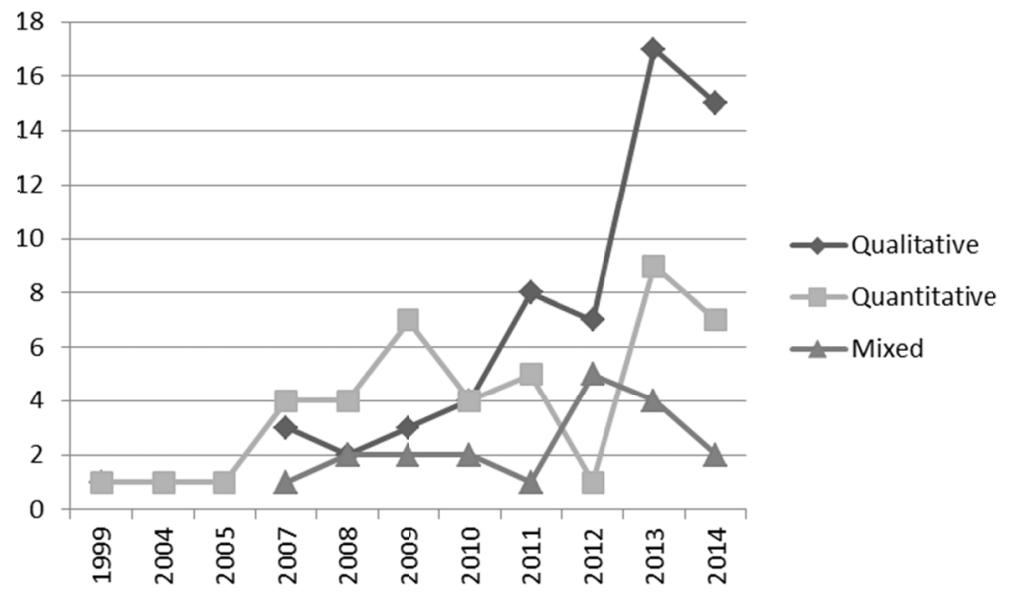

Figure 2. Distribution of research methods according to years

\subsection{Data Collection Instruments Used in Theses}

Table 4 presents the frequency and percentages of data collection instruments used in graduate theses on values education submitted in 1999-2015 in Turkey. As can be seen here, six types of data collection tools were used in the 126 theses. Some of the theses used more than one data collection instrument. The most frequently used tool in the data collection stage is the scale $(38.3 \%)$. The frequency ranking of the other data collection instruments are as follows: document analysis $(28.3 \%)$, interview form $(16.3 \%)$, questionnaire $(10 \%)$, and observation forms $(6.9 \%)$. It is also noteworthy that the graduate theses employing scale and document analysis make up more than half of all studies (66.6\%).

Table 4. Distribution of data collection instruments used in theses by publication years

\begin{tabular}{lll}
\hline Instruments & $\mathrm{f}$ & $\%$ \\
\hline Scale & 61 & 38.3 \\
Document Analysis Form** & 45 & 28.3 \\
Interview Form & 26 & 16.3 \\
Questionnaire & 16 & 10 \\
Observation & 11 & 6.9 \\
Total* & 159 & 100 \\
\hline
\end{tabular}

*More than a single data collection tool were used in some theses.

** It was assumed that document analysis form was used when the measurement instrument was not indicated in theses doing text analysis.

\subsection{Findings Related to Sampling Techniques Used in Theses}

Table 5 shows the sampling techniques used in the graduate theses on values education submitted in 1999-2015 in Turkey according to years. It can be seen that six types of sampling techniques were used: random sampling ( $\mathrm{f}=23$, $56 \%$ ), cluster sampling $(\mathrm{f}=6,14.63 \%)$, stratified sampling $(\mathrm{f}=5,12.19 \%)$, maximum variation $(\mathrm{f}=3,7.31 \%)$, criterion and purposive sampling $(\mathrm{f}=23,56 \%)$. The table shows that more than half of the studies which indicated a certain sampling technique used the random sampling technique. Similarly, an analysis of the distribution of sampling techniques according to years showed that, in 1999 ( $\mathrm{f}=1), 2005$ ( $\mathrm{f}=1), 2007(\mathrm{f}=3), 2009(\mathrm{f}=5), 2010(\mathrm{f}=4), 2013$ ( $\mathrm{f}=3)$, and $2014(\mathrm{f}=2)$, the random sampling technique was preferred mostly, which is parallel to the general distribution. In 2008, on the other hand, mostly cluster sampling was preferred. In 2011, random ( $\mathrm{f}=2)$ and stratified ( $\mathrm{f}=2$ ) sampling techniques were used. In 2012, random, maximum variation, and criterion sampling $(\mathrm{f}=1)$ techniques were used. 
Table 5. Distribution of sampling techniques used in theses according to years

\begin{tabular}{|c|c|c|c|c|c|c|c|c|c|c|c|c|}
\hline Technique & よे & ஜ̊ & ఠ̊ & $\stackrel{\infty}{\circ}$ & ஓे & $\stackrel{\circ}{\circ}$ & $\overline{\overbrace{}}$ & $\stackrel{\sim}{\stackrel{\overbrace{}}{े}}$ & $\stackrel{m}{\stackrel{n}{2}}$ & $\stackrel{\Delta}{\stackrel{d}{~}}$ & $\stackrel{4}{\frac{\pi}{0}}$ & $\frac{0^{0}}{\frac{\pi}{0}}$ \\
\hline Random & 1 & & 3 & 2 & 5 & 4 & 2 & 1 & 3 & 2 & 23 & 56.09 \\
\hline Cluster & & & 1 & 3 & & & & & 1 & 1 & 6 & 14.63 \\
\hline Stratified & & 1 & & & & & 2 & & 1 & 1 & 5 & 12.19 \\
\hline $\begin{array}{l}\text { Maximum } \\
\text { Variation }\end{array}$ & & & & & 1 & & & 1 & & 1 & 3 & 7.31 \\
\hline Criterion & & & & & & 1 & & 1 & & & 2 & 4.87 \\
\hline Purposive & & & & & & & & & 2 & & 2 & 4.87 \\
\hline
\end{tabular}

*Qualitative studies and the studies that did not specify the sampling techniques they used were not analyzed.

Table 6 presents, in frequency and percentage, the samples used in graduate theses on values education submitted in 1999-2015 in Turkey. It is shown that five sample types were used as data sources in the 125 theses analyzed: books $(\mathrm{f}=41,32.5 \%)$, students $(\mathrm{f}=39,30.9 \%)$, teachers-administrators-preservice teachers $(\mathrm{f}=29,23 \%)$, and curricula $(\mathrm{f}=17$, $13.4 \%)$.

Table 6. Distribution of samples across years

\begin{tabular}{|c|c|c|c|c|c|c|c|c|c|c|c|c|c|}
\hline Sample & ळे & 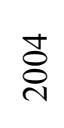 & $\stackrel{\overbrace{}}{8}$ & 용 & $\stackrel{\infty}{\stackrel{\infty}{8}}$ & ஓे & $\stackrel{\circ}{\stackrel{\sim}{\sim}}$ & $\overline{\vec{D}}$ & $\stackrel{\sim}{\stackrel{\sim}{\sim}}$ & $\stackrel{n}{\stackrel{n}{\sim}}$ & $\stackrel{\nabla}{\vec{d}}$ & $\frac{4}{\stackrel{\pi}{0}}$ & $\frac{0^{\circ}}{\frac{\pi}{0}}$ \\
\hline Course book & & & & 2 & 2 & 2 & 4 & 5 & 7 & 9 & 10 & 41 & 32.5 \\
\hline Student & 1 & 1 & & 2 & 3 & 5 & 2 & 7 & 3 & 8 & 7 & 39 & 30.9 \\
\hline Teacher-administrator & & & & 3 & 4 & 4 & 3 & 1 & 3 & 8 & 3 & 29 & 23 \\
\hline Program & 1 & & 1 & 1 & & 2 & 2 & 1 & & 5 & 4 & 17 & 13.4 \\
\hline
\end{tabular}

3.9 Distribution of Data Collection Techniques Used in Graduate Theses

Table 7 demonstrates the data analysis techniques used in graduate theses published in 1999-2015 in Turkey with their distribution across years and percentage values. As can be seen in Table 7, as many as 15 different data analysis techniques were used. These were used in the following order of frequency: descriptive ( $\mathrm{f}=48,17 \%)$, $\mathrm{t}$-test $(\mathrm{f}=48,17 \%)$, document analysis ( $\mathrm{f}=33,11.7 \%)$, anova $(\mathrm{f}=31,11 \%)$, descriptive (qualitative) $(\mathrm{f}=21,7.4 \%)$, content analysis ( $\mathrm{f}=21$, 7.4\%), mann whitney u ( $\mathrm{f}=20,7.1 \%)$, kruskal Wallis $(\mathrm{f}=20,7.1 \%)$, correlation $(\mathrm{f}=19,6.7 \%)$, wilcoxon $(\mathrm{f}=8,2.8 \%)$, regression $(\mathrm{f}=4,1.4 \%)$, manova $(\mathrm{f}=3,1 \%)$, ancova $(\mathrm{f}=2,0.7 \%)$, ki-square $(\mathrm{f}=2,0.7 \%)$, and factor analysis $(\mathrm{f}=1,0.3 \%)$. As regards which years received the highest ratings, the analysis revealed the following results: correlation and document analysis in 1999, descriptive technique in 2004 and 2005, t-test in 2007, 2010, and 2013, descriptive and t-test in 2008, descriptive, t-test, and descriptive (qualitative) in 2011, t-test and document analysis in 2012, and document analysis technique in 2014. 
Table 7. Distribution of data analyses techniques used in theses according to years

\begin{tabular}{|c|c|c|c|c|c|c|c|c|c|c|c|c|c|}
\hline Methods of Analysis* & ळे & ষ্ণ & ڤి & 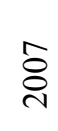 & $\stackrel{\infty}{\circ}$ & 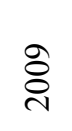 & $\stackrel{\circ}{\stackrel{2}{\sim}}$ & $\overline{\bar{i}}$ & $\stackrel{\sim}{\stackrel{2}{\sim}}$ & $\stackrel{m}{i}$ & $\stackrel{\text { i }}{\stackrel{4}{9}}$ & $\stackrel{4}{\frac{\pi}{0}}$ & $\frac{0^{\circ}}{\frac{\pi}{0}}$ \\
\hline $\begin{array}{l}\text { Descriptive (f, \%, X, } \\
\text { S) }\end{array}$ & & 2 & 2 & 2 & 6 & 6 & 6 & 4 & 3 & 13 & 4 & 48 & 17 \\
\hline t-test & & 1 & & 4 & 6 & 7 & 3 & 2 & 5 & 10 & 5 & 48 & 17 \\
\hline $\begin{array}{l}\text { Document Analysis } \\
\text { (Qualitative) }\end{array}$ & 1 & & & 1 & 3 & 1 & 2 & 4 & 5 & 6 & 10 & 33 & 11.7 \\
\hline Anova & & & & 2 & 5 & 7 & 3 & 1 & 2 & 8 & 3 & 31 & 11 \\
\hline $\begin{array}{l}\text { Descriptive(Qualitativ } \\
\text { e) }\end{array}$ & & & & 1 & 2 & 2 & & 1 & 5 & 7 & 3 & 21 & 7.4 \\
\hline Content (Qualitative) & & & & 1 & & 2 & 3 & 4 & 3 & 5 & 3 & 21 & 7.4 \\
\hline Mann Whitney U & & & & 3 & 3 & 1 & 2 & 2 & & 5 & 4 & 20 & 7.1 \\
\hline Kruskal Wallis & & & & 3 & 4 & 2 & & 3 & 1 & 5 & 2 & 20 & 7.1 \\
\hline Correlation & 1 & & 1 & 1 & 2 & 3 & & 3 & 1 & 3 & 4 & 19 & 6.7 \\
\hline Wilcoxon & & & & 1 & 1 & 1 & 1 & 1 & & 1 & 2 & 8 & 2.8 \\
\hline Regression & & & 1 & & & 1 & & & & 1 & 1 & 4 & 1.4 \\
\hline Manova & & & & & & & & & & 2 & 1 & 3 & 1 \\
\hline Ancova & & & & 1 & & & & & & 1 & & 2 & 0.7 \\
\hline Ki-square & & & 1 & & & & 1 & & & & & 2 & 0.7 \\
\hline Factor Analysis & & & & 1 & & & & & & & & 1 & 0.3 \\
\hline
\end{tabular}

* More than one data analysis technique could be used in a thesis.

\section{Discussion and Conclusion}

This study analyzed a total of 126 post graduate theses written in the field of values education in 1999-2015 in Turkey, focusing on degree, topic, methodology, sample, data collection tools, and data analysis techniques. The majority of the 126 graduate theses analyzed are master's theses, while a minor portion of them are doctoral theses. An increase in the number of graduate theses written on values education has taken place, and year 2013 produced the highest number of theses. The theses studies were conducted in 44 universities. Yeditepe University was the institution wherein most of these theses were written, with all of them being master's theses. It was observed that doctoral theses were written only in 11 universities, with most in Marmara University. The topics which were the foci of graduate these dealing with values education fell into five categories, among which values of students was the most popular. An analysis of the departments to which they were submitted to revealed that, in 1999-2015, the department of educational sciences ranked the first, and elementary childhood education ranked the second.

It was observed that most of the theses studies on values education, which were analyzed as part of this study, were master's theses. This finding is in agreement with that of the study conducted by Baş and Beyhan (2012) and that conducted by Adıgüzel and Ergünay (2012). The former analyzed 22 graduate theses written in 2005-2010, and the latter analyzed graduate theses on values education written in 2000-2011 in Turkey. The findings of a similar study conducted by Elbir and Bağcı (2013) on values education are also in line with this. It is obvious that, if more doctoral studies are conducted on values education, this issue will be studied in greater detail according to scientific criteria, and these studies will make significant contribution to the field (Adigüzel and Ergünay, 2012; Baş and Beyhan, 2012). Therefore, it is crucial that doctoral theses on values education be written. Out of 44 universities where graduate theses on values education were written, only in 11 , doctoral theses were written. This points to the weak proportion of doctoral studies to graduate studies in this field. Values education is an important field that needs to be given greater attention in the doctoral level, and doing so will give direction to the national educational policies and provide guidance to educationalists.

Lee and Taylor (2013) conducted a study wherein they examined a total of 945 research articles published within the past 40 years in the Journal of Moral Education, which generally features publications on moral education, a dimension 
of values education. They discovered that students have a prominent place among the topics of interest. Inevitably, the subject students have been central to values education. This is also confirmed by the results of the present study. It was observed that five major topics were focused on, the highest percentage of which belongs to students' values. This is parallel to the results of the study conducted by Güçlü (2015), which analyzes the research studies on values education in Turkey. As a matter of fact, most studies were observed to have focused on three major topics: students' values, teachers' values and opinions, values in the curriculum (Elbir and Bağc1, 2013; Adıgüzel and Ergünay, 2012; Güçlü, 2015; Baş and Beyhan, 2012). However, the fact that only a limited number of topics have been dealt with in such a wide field as values education may suggest that studies have become repetitive. Balc1 (1993) assert that topics that were dealt with in the graduate theses on values education tend to be the same; the studies tend to replicate each other rather than heading to new topics.

It can be seen that the graduate theses analyzed in this study fall into 12 as regards the departments they were submitted to. Most of the theses were carried out in the field of educational sciences, which is followed by elementary childhood education. This result is aligned with the literature; theses were submitted particularly in education programs under the department of educational sciences, teaching departments, and the departments of social sciences and classroom teaching under the department of elementary childhood education (Baş and Beyhan, 2012; Adıgüzel and Ergünay, 2012). This may be attributed to the fact that values education became an integral part of the curriculum in 2005 with the changes introduced to the curriculum, and the values that are to be gained by students were laid down explicitly especially in the social sciences education program (MEB, 2005).

Ten different research models were observed to have been used in the theses under focus. The most frequently used one is the survey model, followed by experimental and qualitative models. Survey research is defined as an approach to research which aims to describe a past or a present phenomenon as it is (Karasar, 2011). Adıgüzel and Ergünay (2012) analyzed graduate theses on values education to find that survey model is the most frequently used research model. It is also striking that this research model is extensively preferred in educational studies in general (Gül and Sözbilir, 2015; Karadağ 2010; Balc1, 1993; Aypay, et al. 2010; Turan et. al. 2014: Göktaş 2012a; Göktaş 2012b).They are in agreement with the results of the present study. In accordance with the survey design of the theses, data are collected by surveys and questionnaires, and analyzed quantitatively (Adigüzel and Ergünay, 2012). This is an obstacle to probing the problem in data collection and approaching the problem from a relational and empirical viewpoint. According to the findings of Lee and Taylor (2013), the methodologies used are as follows from the most to the least common ones: literature analysis, conceptual research, and quantitative research. However, the rate of literature analysis use dropped from $66.2 \%$ in $1970-1980$ to $28.4 \%$ in $2001-2011$. By contrast, a considerable increase in the qualitative and experimental research can be observed within the past 20 years. This is in concordance with the findings of the research.

The theses that were analyzed within the scope of the research revealed that three methodologies were used: qualitative, quantitative, and mixed. Quantitative methods were predominantly used until 2011, after which a shift has occurred towards the use of qualitative methods. Baş and Beyhan (2012) concluded that almost an equal number of post graduate theses on values education written in the field of education used qualitative and quantitative research methodologies; nevertheless, a recent trend is towards the use of qualitative methodologies. Göktaş (2012a) aimed to identify the trends in research on instructional technologies and concluded that, although quantitative methods have such advantages as greater generalizability of the findings, access to larger samples, time and cost efficiency, use of qualitative and mixed methods tends to increase and the strength of quantitative methods tends to decrease. This is parallel to the findings of the present study. This may be explained by the general growth of the popularity of qualitative methods (Hsu, 2005; Aypay, et al. 2010; Turan, et al. 2014), or the increase in the number of theses focusing on values in the literary and religious works.

Samples and sampling techniques used in graduate theses on values education submitted in Turkey in 1999-2015 were investigated, which pointed to four main data sources: course books, students, teacher-administrators, and instructional programs. It was seen that the most common data source in the theses was samples of course books and students. It may be because, after 2009, literary works have been increasingly analyzed as regards values education. It can also be attributed to the fact that, after 2009, various research on values education in Turkish Language and Religious Education was embarked on, thus literary and religious texts became a focus of theses. On the other hand, it was observed that different sampling techniques were employed in theses, with random sampling being the most widely used one. To sum up, the findings of the study are in accordance with those of many studies conducted in the field of educational sciences (Karadağ, 2010; Karadağ, 2009).

The theses analyzed in the study used the following data collection instruments, from the most to the least frequent one: scale, document analysis, interview, survey, observation. Although qualitative research methods are mostly preferred in the values education field, scale, which is a quantitative data collection instrument, is preferred more. One should notice that the scale, which is advantageous in terms of time, cost, practicality, is the most commonly used data collection tool, 
whereas observation, which requires greater time but allows for access to in-depth data, is preferred rarely. If the only instruments used in the research concerning values education are scale and tests, it will reduce the reliability of data. For this reason, data collection instruments such as observation forms should be widely used so that it will be possible to shed light onto values behind behaviors and opinions (Baş and Beyhan, 2012). Adıgüzel and Ergünay (2012) reached similar results in their study; they concluded that scale and document analyses are the most frequently used data collection tool. In the 126 graduate theses analyzed in this study, a total of 15 different statistical techniques were used, the most common ones being descriptive statistics (f, \%, X, S), t-test, document analysis, and anova techniques. Conflicting results exist in the literature relating to this aspect of the study. Baş and Beyhan, (2012) examined the statistical techniques used in graduate theses on values education; they determined that it is the descriptive statistics (frequency, percentage, arithmetic mean) that was used the most. The second most common statistical technique was variance statistics (t-test, variance analysis, Kruskal Wallis-H test). Very rare as they were, predictive statistical techniques were used. The findings of the study have revealed that, among the quantitative methods, the most popular ones are descriptive and difference analysis methods. Among the qualitative methods, however, the most popular ones are document, content, and descriptive analysis. Finally, the most frequently used quantitative methods in mixed designs are descriptive and difference analysis, whereas the most frequently used qualitative methods are descriptive and content analysis. These findings are in accordance with those of several methodological studies (Göktaş, 2012a). Because values, by their very nature, are about the affective domain, it is crucial that more than one data collection instrument be used. Obviously, such studies will make invaluable contribution to the literature.

To conclude, researchers dealing with values education should be encouraged to carry out doctoral studies and focus on national and international developments to find novel research topics. A multidimensional approach should be adopted when analyzing theses on values education and evaluating them on interdisciplinary level. Thus, it is critical to cooperate with researchers of different fields and work with an interdisciplinary mind. The researcher should design the research according to the problem, rather than seek a problem that would fit the research design to be used. They should be deterred from writing with time concern. It is also remarkable that few theoretical studies exist considering the philosophical foundations of values and approaching the existence of values education critically. Therefore, more of graduate studies, especially doctoral studies, should be conducted in the field. At this point, it is also important that theses should be well-designed methodologically, and to this end, graduate students should be better-equipped as to research methods and statistical knowledge. Although the related field has been classified into the three major headings of personality training, moral education, and values education since the 18th century, few, if any, in-depth studies employing thematic, methodological, and statistical analyses exist. As this is a major discrepancy of the field, further studies using different samples should be conducted on regular intervals.

\section{References}

Adıgüzel, O. C., \& Ergünay, O. (2012). An investigation of dissertations on values in Turkey from the perspective of educational science and teacher training. Electronic Journal of Social Sciences, 11(41), 18-33.

Akbaş, O. (2004). Evaluation of the degree of reaching of affective goals at the elementery level in Turkish national education system (Unpublished doctoral thesis). Gazi University, İstanbul.

Akyüz, Y. (2013). Türk eğitim tarihi (26. Baskı). Ankara: Pegem Yayınc1lı.

Arslan, A. (2005). Felsefeye giriş. Ankara: Adres Yayınları.

Aypay, A., Coruk, A., Yazgan, D., Kartal, O., Çağatay, M., Tuncer, B., \& Emran, B. (2010). The status of research in educational administration: An analysis of educational administration journals, 1999-2007. Eurasian Journal of Educational Research, 39, 59-77.

Balcı, A. (1993). Türkiye'de eğitim araştırmalarının durumu: A.Ü. EBF örneği. Eğitim Bilimleri Birinci Ulusal Kongresi (s. 89-120). Ankara: A.Ü. Eğitim Bilimleri Fakültesi.

Baş, G., \& Beyhan, Ö. (2012). Evaluation of graduate dissertations on values education in Turkey in terms of different. Journal of Values Education, 10(24), 55-77.

Cevizci, A. (2006). Felsefe ansiklopedisi Cilt: 4. Ankara: Babil Yayınc1lı.

Denzin, N. K., \& Lincoln, Y. S. (2005). The sage handbook of qualitative research (Third Edition). California: Sage Publications.

DeRoche, E. F., \& Williams, M. M. (1998). Educating hearts and minds: a comprehensive character education framework. California: Corwin Press.

Doğanay, A. (2006). Değerler eğitimi. C. Öztürk (Ed.). Hayat bilgisi ve sosyal bilgiler öğretimi içinde (s. 255-286). Ankara: Pegem Yayıncilik 
Elbir, B., \& Bağcı, C. (2013). Evaluation of post-graduate theses on values education. Turkish Studies International Periodical for the Languages, Literature and History of Turkish or Turkic, 8(1), 1321-1333. http://dx.doi.org/10.7827/turkishstudies.4250

Elkatmış, M. (2009). Hayat bilgisi öğretiminde değer eğitimi. Bayram Tay (Ed.). Hayat bilgisi öğretimi. (s. 335-365). Ankara: Maya Akademi.

Göktaş, Y., Hasançebi, F., Varışoğlu, B., Akçay, A., Bayrak, N., Baran, M., \& Sözbilir, M. (2012b). Trends in educational research in Turkey: a content analysis. Educational Sciences: Theory \& Practice, 12(1), 443-460.

Göktaş, Y., Küçük, S., Aydemir, M., Telli, E., Arpacık, Ö., Yıldırım, G., \& Reisoğlu, İ. (2012a). Educational technology research trends in Turkey: a content analysis of the 2000-2009 decade. Educational Sciences: Theory \& Practice, 12(1), 177-199.

Güçlü, M. (2015). Studies conducted on values education in Turkey. The Journal of International Social Research, 8(38), 720-732. http://dx.doi.org/10.17719/jisr.20153813681

Gül, S., \& Sözbilir, M. (2014). Biology education research trends in Turkey. Eurasia Journal of Mathematics, Science \& Technology Education, 2015, 11(1), 93-109. http://dx.doi.org/10.12973/eurasia.2015.1309a

Güngör, E. (1998). Değerler psikolojisi üzerinde araştırmalar. İstanbul: Ötüken.

Halstead, J. M. (1996).Values and values education in schools. J. M. Halstead \& M. J. Taylor (Ed.), Values in Education and Education in Values (pp.3-13). Oxon: RoutledgeFalmer.

Hsu, T. (2005). Research methods and data analysis procedures used by educational researchers. International Journal of Research \& Method in Education, 28(2), 109-133. http://dx.doi.org/10.1080/01406720500256194

Karadağ, E. (2009). A thematic and methodological reviewing on doctoral thesis which made at the area of education sciences in Turkey: A case study (Unpublished doctoral thesis). Marmara University, İstanbul.

Karadağ, E. (2010). Research models used in doctoral dissertations in the area of education sciences in Turkey: quality of research and analytical errors. Educational Administration: Theory and Practice, 16(1), 49-71.

Karasar, N. (2011). Bilimsel araştırma yöntemi (22. Baskı). Ankara: Nobel Yayın Dă̆ııım.

Lee, C. M., \& Taylor, M. J. (2013). Moral education trends over 40 years: A content analysis of the Journal of Moral Education (1971-2011). Journal of Moral Education, 42(4), 399-429. http://dx.doi.org/10.1080/03057240.2013.832666

MEB, (1973). Türk milli eğitim temel kanunu. http://mevzuat.meb.gov.tr/html/temkanun_0/ temelkanun_0.html

MEB, (2005). Sosyal bilgiler ögretim programı. http://ttkb.meb.gov.tr/program.aspx? islem=1\&kno=39

Merriam, S. B. (2009). Qualitative research (Third Edition). San Francisco: A Wiley Imprint.

Özlem, D. (2010). Etik ahlak felsefesi (2. Baskı). İstanbul: Say Yayınları.

Patton, M. Q. (2002). Qualitative research \& evaluation methods (Third Edition). London: Sage Publications.

Stephenson, J., Ling, L., Burman, E., \& Cooper, M. (Der.) (1998). Values in education. Newyork: Routledge

Tarman, B., \& Kuran, B. (2014). Teachers' perceptions about the relationship between learning levels of values in citizenship and human rights course and the environment. Gazi University Journal Gazi Educational Faculty GUJGEF, 34(2), 293-319

Turan, S., Karadağ, E., Bektaş, F., \& Yalçın, M. (2014). Knowledge production in educational administration in Turkey: an overview of researches in journal of educational administration: Theory and practice -2003 to 2013-. Educational Administration: Theory and Practice, 20(1), 93-119. http://dx.doi.org/10.14527/kuey.2014.005

Ulusoy, K., \& Dilmaç, B. (2012). Değerler eğitimi. Ankara: Pegem Yayıncılık.

Yel, S., \& Aladağ, S. (2009). Sosyal bilgilerde değerlerin öğretimi. Mustafa Safran (Ed.). Sosyal bilgiler öğretimi (s. 118-145). Ankara: Pegem Yayınc1lik.

Yıldırım, A., \& Şimşek, H. (2011). Sosyal bilimlerde nitel araştırma yöntemleri (8. Baskı). Ankara: Seçkin Yayıncılık. 


\section{Appendix A}

Appendix A. Distribution of theses according to universities

\begin{tabular}{|c|c|c|c|c|c|c|}
\hline \multirow{2}{*}{ Universities } & \multicolumn{2}{|c|}{ Master's } & \multicolumn{2}{|c|}{ Doctoral } & \multicolumn{2}{|c|}{ Total } \\
\hline & $\mathrm{f}$ & $\%$ & $\mathrm{f}$ & $\%$ & $\mathrm{f}$ & $\%$ \\
\hline Yeditepe University & 14 & 14.8 & 0 & 0 & 14 & 11.1 \\
\hline Marmara University & 11 & 10.3 & 1 & 5 & 12 & 9.5 \\
\hline Gazi University & 5 & 4.7 & 4 & 20 & 9 & 7.1 \\
\hline Atatürk University & 5 & 4.7 & 3 & 15 & 8 & 6.3 \\
\hline Hacettepe University & 3 & 2.9 & 2 & 10 & 5 & 3.9 \\
\hline Selçuk University & 2 & 1.8 & 3 & 15 & 5 & 3.9 \\
\hline Çanakkale On sekiz Mart University & 3 & 2.9 & 1 & 5 & 4 & 3.1 \\
\hline İnönü University & 4 & 3.7 & 0 & 0 & 4 & 3.1 \\
\hline Karadeniz Teknik University & 4 & 3.7 & 0 & 0 & 4 & 3.1 \\
\hline Necmettin Erbakan University & 3 & 2.9 & 1 & 5 & 4 & 3.1 \\
\hline Uşak University & 4 & 3.8 & 0 & 0 & 4 & 3.1 \\
\hline Yüzüncü yıl University & 4 & 3.7 & 0 & 0 & 4 & 3.1 \\
\hline Erciyes University & 2 & 1.8 & 1 & 5 & 3 & 2.3 \\
\hline Firat University & 2 & 1.8 & 1 & 5 & 3 & 2.3 \\
\hline Mustafa Kemal University. & 3 & 2.9 & 0 & 0 & 3 & 2.3 \\
\hline Sakarya University & 3 & 2.9 & 0 & 0 & 3 & 2.3 \\
\hline Celal Bayar University & 2 & 1.8 & 0 & 0 & 2 & 1.5 \\
\hline Dumlupınar University & 2 & 1.8 & 0 & 0 & 2 & 1.5 \\
\hline İstanbul University & 2 & 1.8 & 0 & 0 & 2 & 1.5 \\
\hline Niğde University. & 2 & 1.8 & 0 & 0 & 2 & 1.5 \\
\hline Uludağ University & 1 & 0.9 & 1 & 5 & 2 & 1.5 \\
\hline Zonguldak Karaelmas University & 2 & 1.8 & 0 & 0 & 2 & 1.5 \\
\hline Ondokuz Mayıs University & 2 & 1.8 & 0 & 0 & 2 & 1.5 \\
\hline Abant İzzet Baysal University & 2 & 1.8 & 0 & 0 & 2 & 1.5 \\
\hline Akdeniz University & 2 & 1.8 & 0 & 0 & 2 & 1.5 \\
\hline Anadolu University & 0 & 0 & 1 & 5 & 1 & 0.7 \\
\hline Ankara University & 1 & 0.9 & 0 & 0 & 1 & 0.7 \\
\hline Çukurova University & 1 & 0.9 & 0 & 0 & 1 & 0.7 \\
\hline Dicle University & 1 & 0.9 & 0 & 0 & 1 & 0.7 \\
\hline Ege University & 1 & 0.9 & 0 & 0 & 1 & 0.7 \\
\hline Erzincan University & 1 & 0.9 & 0 & 0 & 1 & 0.7 \\
\hline Eskişehir Osmangazi University & 1 & 0.9 & 0 & 0 & 1 & 0.7 \\
\hline Gaziosmanpasa University & 1 & 0.9 & 0 & 0 & 1 & 0.7 \\
\hline Hitit University & 1 & 0.9 & 0 & 0 & 1 & 0.7 \\
\hline Kocaeli University & 1 & 0.9 & 0 & 0 & 1 & 0.7 \\
\hline Mehmet Akif Ersoy University & 1 & 0.9 & 0 & 0 & 1 & 0.7 \\
\hline Mersin University & 0 & 0.0 & 1 & 5 & 1 & 0.7 \\
\hline Muğla University & 1 & 0.9 & 0 & 0 & 1 & 0.7 \\
\hline Orta Doğu Teknik University & 1 & 0.9 & 0 & 0 & 1 & 0.7 \\
\hline Pamukkale University & 1 & 0.9 & 0 & 0 & 1 & 0.7 \\
\hline Yıldırım Beyazıt University & 1 & 0.9 & 0 & 0 & 1 & 0.7 \\
\hline Adnan Menderes University & 1 & 0.9 & 0 & 0 & 1 & 0.7 \\
\hline Afyon Kocatepe University & 1 & 0.9 & 0 & 0 & 1 & 0.7 \\
\hline Aksaray University & 1 & 0.9 & 0 & 0 & 1 & 0.7 \\
\hline Total & 106 & 100 & 20 & 100 & 126 & 100 \\
\hline
\end{tabular}

\section{$(\mathrm{CC}) \mathrm{EY}$}

This work is licensed under a Creative Commons Attribution 3.0 License. 